\title{
Identification of long-term high-flow regime changes in selected stations along the Danube River
}

\author{
Pavla Pekárová ${ }^{1}$, Branislav Pramuk $^{1}$, Dana Halmová ${ }^{1 *}$, Pavol Miklánek $^{1}$, Stevan Prohaska ${ }^{2}$, Ján Pekár ${ }^{3}$ \\ ${ }^{1}$ Institute of Hydrology, Slovak Academy of Sciences, Dúbravská cesta 9, 84104 Bratislava, Slovakia. \\ 2 Jaroslav Černi Institute for the Development of Water Resources, Jaroslava Černog 80, 11226 Belgrade, Serbia. \\ ${ }^{3}$ Comenius University in Bratislava, Faculty of Mathematics, Physics, and Informatics, Mlynská dolina F1, 84248 Bratislava, Slovakia. \\ * Corresponding author. Tel.: +4212 44259404. Fax:+4212 44259404. E-mail: halmova@uh.savba.sk
}

\begin{abstract}
The aim of the paper is to study spatial and temporal changes in the magnitude, duration and frequency of high flows in the Danube basin. A hydrological series of the mean daily discharges from 20 gauging stations (operated minimally since 1930) were used for the analysis of changes in the daily discharges. The high flow events were classified into three classes: high flow pulses, small floods, and large floods. For each year and for each class, the means of the peak discharges, the number and duration of events, and the rate of changes of the rising and falling limbs of the waves were determined. The long-term trends of the annual time series obtained were analyzed and statistically evaluated.

The long-term high flow changes were found to be different in three individual high flow classes. The duration of the category of high flow pulses is decreasing at 19 stations on the Danube and is statistically significant at the Linz, Vienna, Bratislava and Orsova stations. The frequency of the high flow pulses is increasing in all 20 stations. Also, the rising and falling rates of the high flow pulse category are increasing at the majority of the stations. The long-term trends of the selected characteristics of the small floods are very similar to the trends of the high flow pulses, i.e., the duration of small floods is decreasing, and their mean number per year is increasing. In the category of large floods the changes were not proved.
\end{abstract}

Keywords: Floods; Hydrological regime; Long streamflow series; Danube River; Flow thresholds; Flood trends.

\section{INTRODUCTION}

Destructive and costly floods occur very often in Europe; thus, the need for hydrological research continues. In recent years, considerable attention has been devoted to the detection and analysis of changes in such flood characteristics as annual maximum flows, maximum water stages, and flood frequencies. Beurton and Thieken (2009) investigated the seasonal distribution of annual maximum floods at 481 gauge stations across Germany and created a map with three regions that represented homogeneous flood regimes. Petrow and Merz (2009) detected spatially and seasonally coherent changes in the maximum flood flows across Germany between 1951 and 2002 and argued that these spatially homogeneous and large-scale responses may be caused by large-scale drivers such as climate variability. Vorogushyn and Merz (2013) investigated the role of river training in changes in the annual maximum daily flows at Rhine gauges. In particular, the effects of the Rhine weir cascade and a series of detection basins were investigated. In this work, a unique set of homogenisation relationships was compiled for eight gauges along the Rhine. They were applied to the original discharge records to produce a homogenised series of maximum annual flows that would occur if the construction of the Rhine weir cascade and the series of detention basins had not taken place between 1955 and 2009. Based on the comparison between the original and homogenised flood time series, it is possible to single out the effect of river training on flood trends. The work showed that the significant positive trends detected in the historical flood records at the eight gauges along the Rhine were seriously contaminated by a signal attributable to the river training measures. According to Merz et al. (2014), the analysis would perhaps have moved from the annual maximum or peak-over-threshold floods to looking at extreme floods in terms of their discharges, volumes and durations as well as their space and time structures over a season, a decade, or longer. The volume and duration of flooding are directly tied to inundation characteristics; hence, they represent how the strength and recurrence characteristics of large-scale atmospheric fluxes (that bring moisture into a region) interact with a catchment's hydrological processes.

Several studies that have considered changes in flood records on larger and trans-national scales exist; they include the Nordic countries, Central Europe, the Baltic States, and North America (Blöschl et al., 2012; Kundzewicz et al., 2012; Lindström and Bergström, 2004, etc.). A synthesis of these studies (Hall et al., 2014), does not, however, indicate a clear and consistent pattern across Europe.

An alternative to assessments of flood regime changes based on trend analyses of annual maximum discharges is an assessment of characteristics that describe the intra and inter-annual variability in water flow conditions (including the magnitude, frequency, duration, timing and rate of change). Mathews and Richter (2007) analysed the "environmental flow components" that characterize a hydrograph in a manner that is representative of key flow-ecology relationships. Gao et al. (2009) developed a small set of independent and representative hydrological indicators that can characterize hydrological alterations caused by reservoirs and other forms of river regulation. The results revealed that the recently introduced metrics known as "ecodeficits" and "eco-surpluses" can provide a good overall representation of the degree of alteration of a streamflow time series. Pyron and Neumann (2008) examined flow alterations in a single watershed, i.e., the Wabash River, and suggested their potential impact on aquatic assemblages. They show that the changes in a flood regime are related to the size of the basins and anthropogenic activities such as reservoir operations and agricultural practices. 
The pulsing of the river discharge - the flood pulse - is the major force controlling biota in river floodplains (Junk et al., 1989). For example, the migration of particular fish coincide with spring and summer Danube floods. According to Holčík (2003), the optimal situation should be that both floods cover the entire floodplain. The commencement, culmination, and fading away of floods should simulate the situation which existed before the construction of river dikes. To protect the diversity of fauna and flora, it is important to preserve the natural course of the filling and subsequent draining of a flooded area.

The objective of this study is to evaluate alternative characteristics for describing flood regime changes along the Danube River. A continuous time series of daily discharges from twenty gauging stations along the Danube River were used. The longest records of the datasets provide a unique opportunity to study long-term trends in flood data and consequently detect largescale changes in the risk of flooding along the Danube River.

The Danube River is a significant international river, and all the changes in its runoff regimes are of very high economic and social importance for all the Danube countries. An assessment of the runoff changes along the whole river course provides us with a large-scale view of the similarity or variability of the runoff regimes.

\section{MATERIALS Study area}

The Danube River Basin (DRB) covers a vast area of $817,000 \mathrm{~km}^{2}$ (10\% of the European continent), making it the second largest river basin in Europe after the Volga. It is also the basin that covers the greatest number of countries in the world. Some countries such as Austria, Hungary, Romania, Serbia and the Slovak Republic are almost completely situated within the DRB, whereas less than $5 \%$ of the territories of Albania, Italy, Macedonia, Montenegro, Poland and Switzerland lie in the basin.

The length of the Danube River is approximately $2,830 \mathrm{~km}$. The river is formed in the Black Forest in Germany at the confluence of the Brigach and Breg streams. It discharges into the Black Sea via the Danube Delta, which lies in Romania and Ukraine. With a long-term annual average discharge of $6,500 \mathrm{~m}^{3} \mathrm{~s}^{-1}$, the Danube is the largest tributary of the Black Sea.

The Danube Basin can be subdivided into four main parts:

i. the Upper Danube Region, between its springs and the

Devin Gate, its gauging stations from Berg to Bratislava (Bratislava: $133 \mathrm{~m}$ a.s.l., 1,880 r km (river kilometer), basin area: $131,338 \mathrm{~km}^{2}$, long-term annual average discharge $\left.2,051 \mathrm{~m}^{3} \mathrm{~s}^{-1}\right)$

ii. the Central Danube Region between the Devin Gate and the Iron Gate, gauging stations from Nagymaros to Turnu Severin/Orsova (Turnu Severin/Orsova: $60 \mathrm{~m}$ a.s.1., 930 $\mathrm{r} \mathrm{km}$, basin area $444,894 \mathrm{~km}^{2}$, long-term annual average discharge $5,585 \mathrm{~m}^{3} \mathrm{~s}^{-1}$ at gauge);

iii. the Lower Danube Region, between the Iron Gate and the Danube's Delta (Reni: 4 m a.s.l., $132 \mathrm{r} \mathrm{km}$, basin area: $230,768 \mathrm{~km}^{2}$, long-term annual average discharge $6,563 \mathrm{~m}^{3} \mathrm{~s}^{-1}$ ); iv. the Danube Delta at the Black Sea coast.

Due to its large area and diverse relief, the DRB has a varied climate and a multiplicity of habitats. Depending on the region, the mean annual precipitation totals range from less than $500 \mathrm{~mm}$ in the Danube Delta to more than 2,500 $\mathrm{mm}$ per year in the Alps, which strongly affect the runoff from the river basins and discharge levels in the streams (Petrovič et al.,
2006). Pekárová et al. (2008) and Pekárová (2009) analyzed the variability of the multiannual runoff in the Upper Danube region. In the Upper Danube basin, the runoff corresponds to the runoff regime of the Alpine tributaries, where the maximum occurs in June (when the snow and ice melting in the Alps region is the most intensive). In the Central Danube basin the high-flow period may last up to four months, with two runoff peaks in June and April. The April peak is local and is caused by the addition of waters from the melting snow on the plains and from the early spring rains in the lowlands and the low mountain areas. Due to its low precipitation totals and high summer temperatures, the Danube Delta area can be considered as a region with temperate climate zones with the character of a steppe (Wachter et al., 2005). The regulation and excavation of a number of the canals of the Danube River branches had a very important impact on the hydrology and ecology of the Danube Delta before 1975. Engineering schemes to control the water flow in the Delta date from the second half of the $19^{\text {th }}$ century with river regulation in the Ukrainian and in Romanian sections.

\section{Hydrological data}

In this work we used mean daily discharge data from the database of the project "Flood regime of rivers in the Danube River Basin", which was developed within the Regional collaboration of the Danube countries of the International Hydrological Programme (IHP) of UNESCO (Pekárová, 2009; Pekárová et al., 2011, 2014). From the database of the mean daily discharges along the Danube River (24 water gauging stations -7 European countries), 20 gauging stations were chosen for the analysis of changes in the daily discharges (Fig. 1). We selected the gauging stations with the longest daily discharge time series of observations.

In Table 1, there is a list of the selected water gauge stations along the Danube with the altitude of the gauge zero [m a.s.l.] (recalculated into the Baltic system), the length of the periods analyzed, the long-term average annual discharge $\left(Q_{a}\right)$, and the runoff depths $\left(R_{a}\right)$ in the periods analyzed.

The time series of the daily data were checked for random errors in the first step at all the twenty stations along the Danube. In two stations a one-month gap in the series occurred in 1944. These data were completed by linear regression using the neighbouring stations.

\section{METHODS}

When analysing a hydrograph, it is possible to show the flow variations and identify the periods of high flows. We took into account all the flood events and not only the annual maximum floods. The high flows were separated from the daily hydrographs and were divided according to the method described by The Nature Conservancy (2009) into three groups:

1) high flow pulses (short-duration high flows within a stream channel that occur during or immediately following a storm event, including any rising water that did not overtop the river channel banks);

2) small floods (including all the rises in rivers that overtopped the main channel but did not include more extreme, and less frequent, floods);

3) large floods (floods that rearrange both the biological and physical structures of a river and its floodplain).

The scheme of the classification of the three high flow classes is shown in Fig. 2. 
Table 1. List of selected stations in the Danube basin. No. - station number, C - country, $\mathrm{r} \mathrm{km} \mathrm{-} \mathrm{river} \mathrm{km,} \mathrm{LAT} \mathrm{-} \mathrm{latitude,} \mathrm{LONG} \mathrm{-} \mathrm{longitude,}$ ALT. - altitude, $Q_{a}$ - long-term average annual discharge, $R_{a}$ - long-term mean annual runoff depth.

\begin{tabular}{|c|c|c|c|c|c|c|c|c|c|c|c|}
\hline \multirow[t]{2}{*}{ No. } & \multirow{2}{*}{$\begin{array}{l}\text { STATION } \\
\text { Danube } \\
\text { new /old }\end{array}$} & \multirow[t]{2}{*}{$\mathrm{C}$} & \multirow{2}{*}{$\begin{array}{l}\mathrm{rkm} \\
{[\mathrm{km}]}\end{array}$} & \multirow{2}{*}{$\begin{array}{l}\text { AREA } \\
{\left[\mathrm{km}^{2}\right]}\end{array}$} & \multirow[t]{2}{*}{ LAT } & \multirow[t]{2}{*}{ LONG } & \multirow{2}{*}{$\begin{array}{c}\text { ALT. } \\
\text { [m a.s.1.] }\end{array}$} & \multicolumn{2}{|c|}{ DAILY DATA } & \multirow{2}{*}{$\begin{array}{c}Q_{a} \\
{\left[\mathrm{~m}^{3} \mathrm{~s}^{-1}\right]}\end{array}$} & \multirow{2}{*}{$\begin{array}{r}R_{a} \\
{[\mathrm{~mm}]}\end{array}$} \\
\hline & & & & & & & & $\begin{array}{l}\text { from } \\
\text { [year] }\end{array}$ & $\begin{array}{c}\text { to } \\
\text { [year] }\end{array}$ & & \\
\hline 1 & Berg & $\mathrm{DE}$ & 2,613 & 4,047 & 48.27 & 9.73 & 489.9 & 1931 & 2013 & 38.4 & 299 \\
\hline 2 & Ingolstadt & DE & 2,457 & 20,001 & 48.75 & 11.42 & 360.4 & 1924 & 2013 & 313.0 & 494 \\
\hline 3 & $\begin{array}{l}\text { Schwabelweis/ } \\
\text { Regensburg }\end{array}$ & DE & 2,376 & 35,399 & 49.02 & 12.14 & 324.5 & 1923 & 2013 & 445.0 & 396 \\
\hline 4 & Pfelling & $\mathrm{DE}$ & 2,306 & 37,757 & 48.88 & 12.75 & 308.2 & 1925 & 2013 & 468.8 & 392 \\
\hline 5 & Hofkirchen & DE & 2,257 & 47,496 & 48.68 & 13.12 & 299.6 & 1901 & 2013 & 640.0 & 425 \\
\hline 6 & Achleiten & DE & 2,223 & 76,653 & 48.58 & 13.50 & 287.7 & 1901 & 2013 & 1,428 & 587 \\
\hline 7 & Linz/ Aschach & $\mathrm{AT}$ & 2,135 & 79,490 & 48.31 & 14.30 & 248.2 & 1931 & 2007 & 1,464 & 581 \\
\hline 8 & $\begin{array}{l}\text { Kienstock/ } \\
\text { Stein-Krems }\end{array}$ & $\mathrm{AT}$ & 2,003 & 96,045 & 48.38 & 15.46 & 189.5 & 1900 & 2006 & 1,892 & 621 \\
\hline 9 & Wien-Nussdorf & $\mathrm{AT}$ & 1,934 & 101,731 & 48.25 & 16.30 & 157.0 & 1900 & 2006 & 1,920 & 595 \\
\hline 10 & Devin/ Bratislava & SK & 1,869 & 131,338 & 48.14 & 17.11 & 129.3 & 1876 & 2013 & 2,050 & 492 \\
\hline 11 & Nagymaros & $\mathrm{HU}$ & 1,695 & 183,534 & 47.78 & 18.95 & 99.8 & 1893 & 2007 & 2,336 & 401 \\
\hline 12 & Mohács & $\mathrm{HU}$ & 1,447 & 209,064 & 46.00 & 18.67 & 79.4 & 1930 & 2007 & 2,354 & 355 \\
\hline 13 & Bezdan & $\mathrm{RS}$ & 1,426 & 210,250 & 45.85 & 18.87 & 81.1 & 1931 & 2010 & 2,357 & 354 \\
\hline 14 & Bogojevo & $\mathrm{RS}$ & 1,367 & 251,593 & 45.53 & 19.08 & 78.0 & 1931 & 2007 & 2,893 & 363 \\
\hline 15 & Pancevo & RS & 1,153 & 525,009 & 44.87 & 20.64 & 67.8 & 1931 & 2007 & 5,320 & 320 \\
\hline 16 & Veliko Gradiste & RS & 1,060 & 570,375 & 44.80 & 21.40 & 62.7 & 1931 & 2007 & 5,560 & 307 \\
\hline 17 & $\begin{array}{l}\text { Orsova/ } \\
\text { Turnu Severin }\end{array}$ & $\mathrm{RO}$ & 955 & 576,232 & 44.70 & 22.42 & 44.4 & 1850 & 2005 & 5,602 & 307 \\
\hline 18 & Zimnicea & RO & 554 & 658,400 & 43.63 & 25.36 & 16.2 & 1931 & 2010 & 6,001 & 287 \\
\hline 19 & Reni & UA & 132 & 805,700 & 45.28 & 28.13 & 4.0 & 1921 & 2010 & 6,563 & 257 \\
\hline 20 & Ceatal Izmail & RO & 72 & 807,000 & 45.22 & 28.73 & 0.6 & 1931 & 2010 & 6,415 & 251 \\
\hline
\end{tabular}

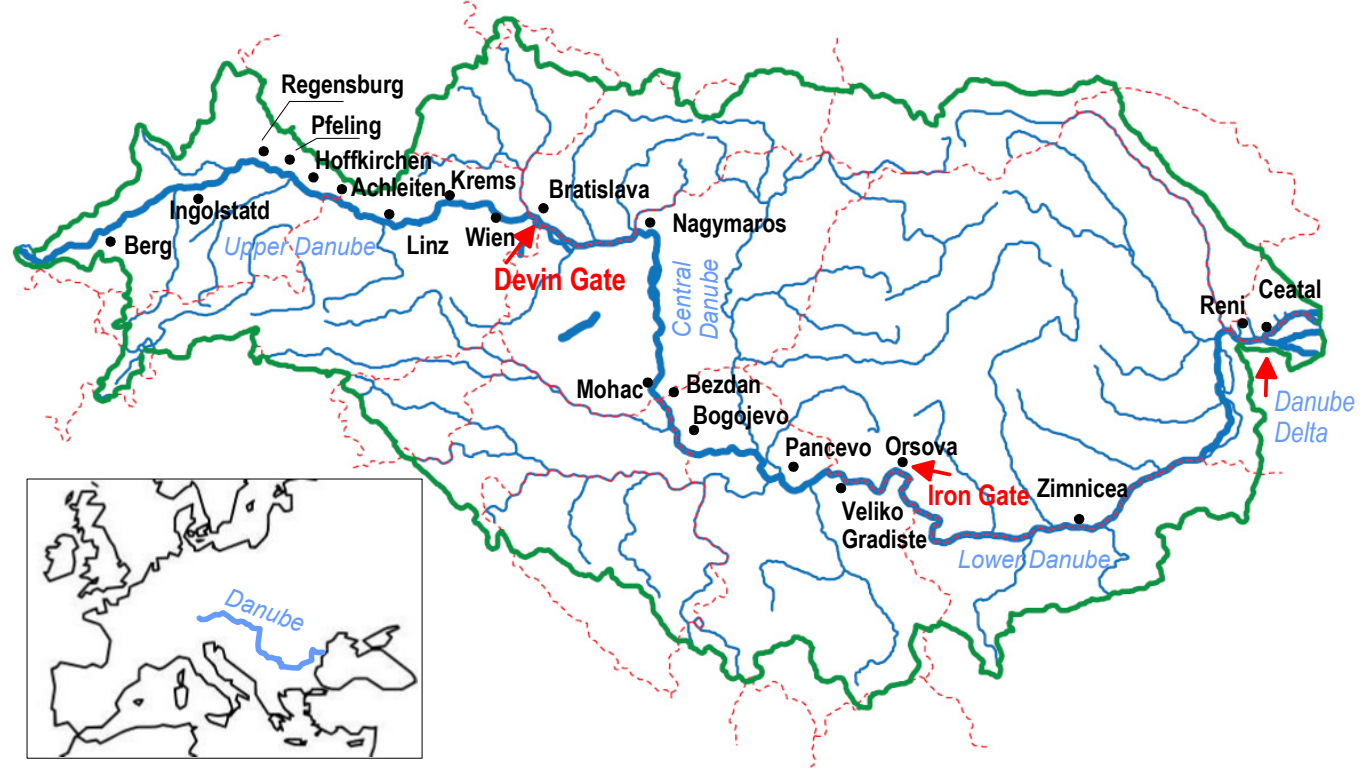

Fig. 1. The Danube River basin, location in Europe, main water gauging stations.

All the discharges that exceeded the $75^{\text {th }}$ percentile of the whole period were classified as high flows, and all the discharges that were below the $50^{\text {th }}$ percentile were classified as low flows. Between these two levels, a high flow began when the discharge increased by more than $25 \%$ per day and ended when the discharge decreased by less than $10 \%$ per day. A small flood event is defined as a high flow with a peak discharge greater than a 2-year return interval event, and a large flood event is defined as a high flow with a peak discharge greater than a 10 -year return interval event. 


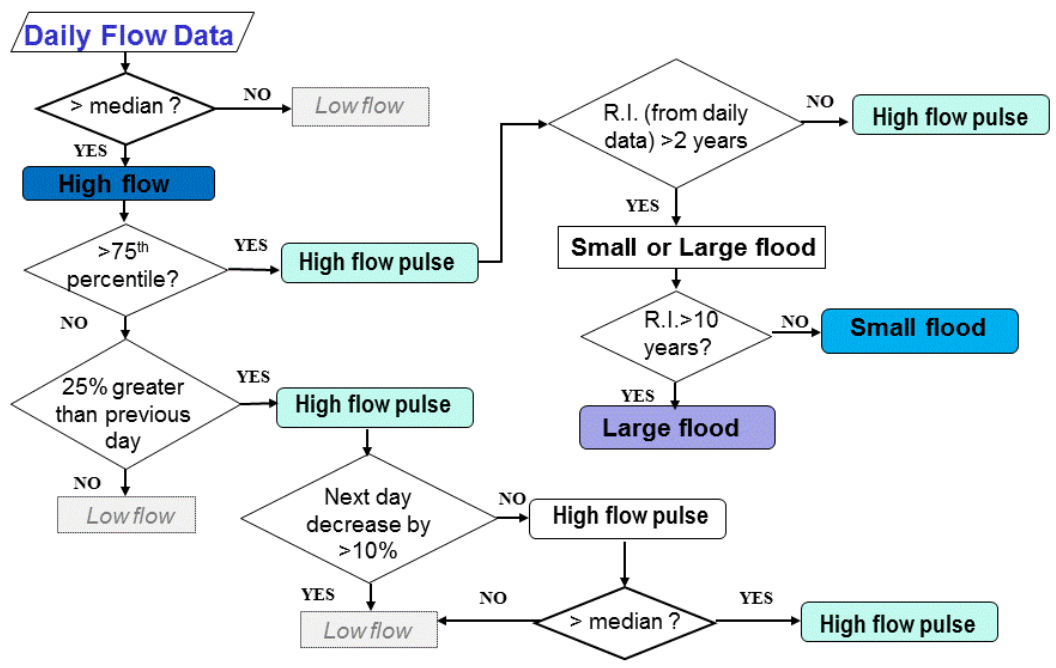

Fig. 2. The scheme of the hydrograph classification ("R.I." means "return interval") according to Hersh and Maidment (2006).



Fig. 3. Classification of hydrographs into different flow types (large floods - dark blue, small floods - blue, high flow pulses - green), Danube: Bratislava water gauge. Detail from the years 1876-1880.

For a 10 -year return interval, the $90^{\text {th }}$ percentile of all the annual maximum flood peaks was found, and for a 2-year return interval, the $50^{\text {th }}$ percentile was found. All the events with peaks greater than the discharge value that corresponds to the large flood return interval were classified as large floods, and all the events with peaks less than this value but greater than the discharge value that corresponds to the small flood return interval were classified as small floods. All the initial high flows not classified as small floods or large floods were classified as high flow pulses.

A more detailed description of the flow classifications is described in The Nature Conservancy (2009). The threshold values of the flows may be different at the individual stations along the Danube River, thus better reflecting the local conditions of the Danube riverbed. For comparison purposes, the same thresholds in all the stations were used in this study. The example for the Bratislava station is presented in Fig. 3.

Based on the above-mentioned references and commonly used statistical methods of flow analysis, we analysed the following daily discharge time series characteristics (separately for the categories of high flow pulses, small floods and large floods):
1) Mean values of the peak discharge during events for each year;

2) Frequency of events during each year;

3) Duration of flow events (mean duration of events in days);

4) Changes in the rate of discharge (rising and falling rates: mean of all the positive/negative differences between the consecutive daily values).

For the calculation of the selected high flow indices, IHA software was used (The Nature Conservancy, 2009).

\section{RESULTS}

The analysis of the long-term trends of the five hydrological characteristics (peak discharges, number and duration of events, and the rising and falling rates of the waves) for the three categories (high flow pulse, small floods, and large floods) was done at all of the 20 stations along the Danube. The most interesting results are presented as a comparison of four stations: one in the upper (Hofkirchen), one in the central (Bratislava), and two in the lower Danube basin (Zimnicea and Reni). 
Table 2. Discharge thresholds in the stations along the Danube River $\left[\mathrm{m}^{3} \mathrm{~s}^{-1}\right]$.

\begin{tabular}{lccc}
\hline & \multicolumn{3}{c}{ minimum peak discharge threshold $\left[\mathrm{m}^{3} \mathrm{~s}^{-1}\right]$} \\
& Large flood & Small flood & High flow pulse \\
\hline Berg & 304.5 & 176 & 47.2 \\
Ingolstadt & 1,448 & 1,050 & 379 \\
Regensburg & 2,119 & 1,495 & 540 \\
Pfeling & 2,240 & 1,450 & 548 \\
Hofkirchen & 2,545 & 1,825 & 768 \\
Achleiten & 5,140 & 3,705 & 1,750 \\
Linz & 5,132 & 3,744 & 1,806 \\
Stein-Krems & 6,873 & 5,158 & 2,275 \\
Wien & 6,860 & 5,399 & 2,365 \\
Bratislava & 8,239 & 5,321 & 2,539 \\
Nagymaros & 7,196 & 5,280 & 2,890 \\
Mohacs & 6,390 & 4,875 & 2,880 \\
Bezdan & 6,309 & 4,890 & 2,900 \\
Bogojevo & 7,180 & 5,594 & 3,570 \\
Pancevo & 12,500 & 9,654 & 6,721 \\
Veliko Gradiste & 13,400 & 10,190 & 7,012 \\
Orsova & 13,150 & 10,240 & 7,159 \\
Zimnicea & 13,990 & 10,770 & 7,640 \\
Reni & 13,700 & 11,350 & 8,320 \\
Caetal Izmail & 13,460 & 10,700 & 8,290 \\
\hline
\end{tabular}

At the Hofkirchen station the mean daily discharge of $786 \mathrm{~m}^{3} \mathrm{~s}^{-1}$ was computed as the threshold for the peaks of the high flow events and corresponds to the $75^{\text {th }}$ percentile of the series. The events with maximum mean daily discharges between $1,825 \mathrm{~m}^{3} \mathrm{~s}^{-1}$ and $2,545 \mathrm{~m}^{3} \mathrm{~s}^{-1}$ were classified in the category of small floods. These thresholds correspond to 2-year and 10-year return periods, respectively. The events with maximum mean daily discharges higher than $2,545 \mathrm{~m}^{3} \mathrm{~s}^{-1}$ were classified in the category of large floods. At the Bratislava station, the classification followed the threshold values of 2,539 $\mathrm{m}^{3} \mathrm{~s}^{-1}$ (lower for high flows), $5,320 \mathrm{~m}^{3} \mathrm{~s}^{-1}$ (upper for high flows and lower for small floods), and $8,239 \mathrm{~m}^{3} \mathrm{~s}^{-1}$ (upper for small floods and lower for large floods). At the Zimnicea station the lower threshold for high flows was a daily discharge of 7,640 $\mathrm{m}^{3} \mathrm{~s}^{-1}$. The events with maximum mean daily discharges between $10,770 \mathrm{~m}^{3} \mathrm{~s}^{-1}$ and $13,990 \mathrm{~m}^{3} \mathrm{~s}^{-1}$ were classified in the category of small floods, and higher discharges were classified as large floods. At the Reni station the high flows were above $8,320 \mathrm{~m}^{3} \mathrm{~s}^{-1}$, and the events with maximum mean daily discharges between $11,350 \mathrm{~m}^{3} \mathrm{~s}^{-1}$ and $13,700 \mathrm{~m}^{3} \mathrm{~s}^{-1}$ were classified in the category of small floods. Large floods were above $13,700 \mathrm{~m}^{3} \mathrm{~s}^{-1}$. The mean annual minimum peak discharge thresholds in all the stations along the Danube River are listed in Table 2.

The course of the computed characteristics at gauging stations along the Danube River (high flow category thresholds, means of high flow categories, mean duration, mean frequency, mean day of occurrence - timing, mean rise rate) is presented in Fig. 4.

Fig. 5 presents the magnitudes of the peak discharges in the high flow pulse category for every year at the four selected stations. The magnitude of the high flow pulses did not change significantly in the three upper stations, but we can observe the increase in the magnitude for this category at the Reni station. It should be considered whether this result is a consequence of the Danube river regulation. In the future, a detailed analysis and further discussions between hydrologists and water managers will be required.
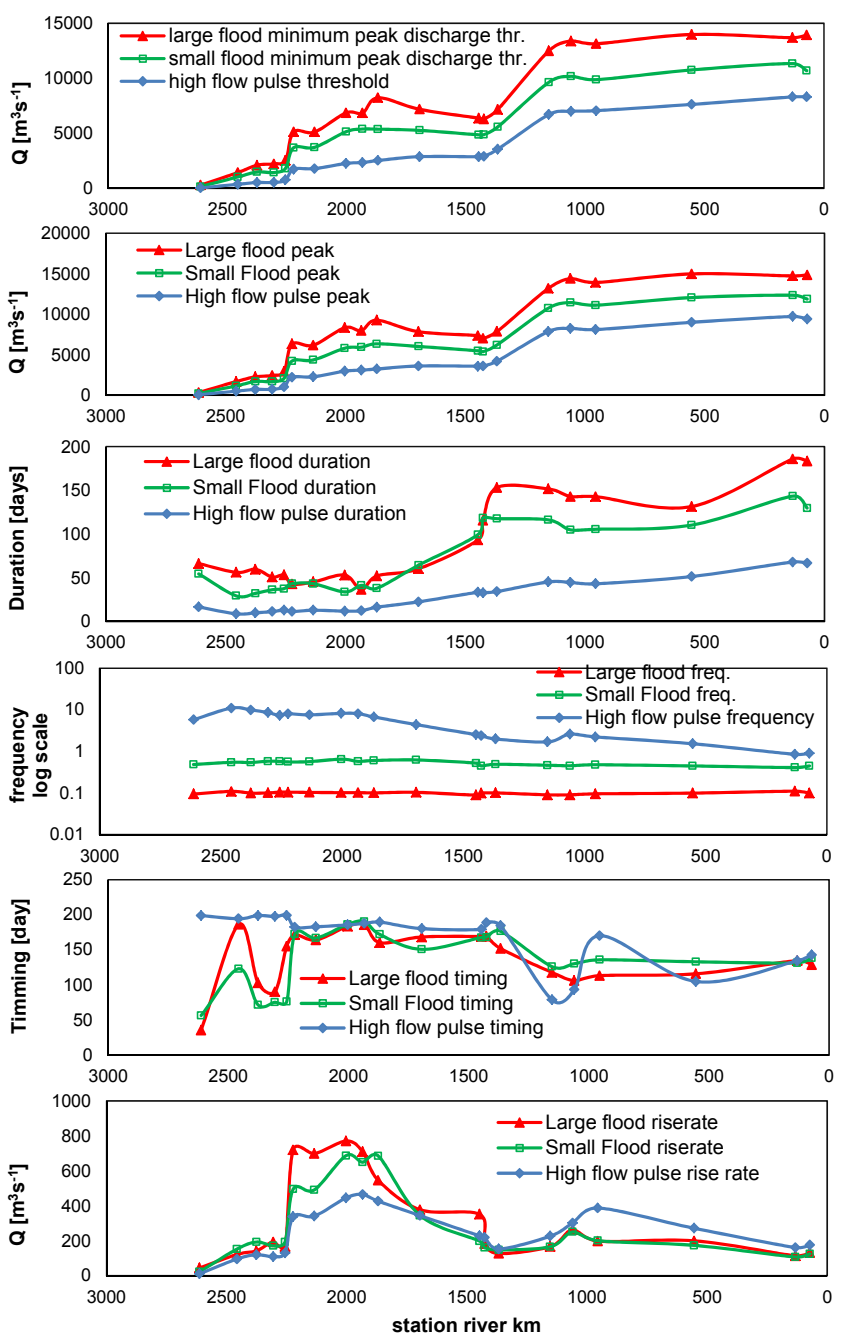

Fig. 4. Course of the computed characteristics at the stations along the Danube River (high flow categories thresholds; means of high flow category - mean duration; mean frequency; mean timing; mean rise rate).

The duration and frequency of the high flow pulses (mean duration of events in days, number of events within each year) from the selected stations are given in Fig. 6 a, b. The mean of the duration of the high flow pulses in one year is 13.1 days at the Hofkirchen gauge, 16.0 days at the Bratislava station, 51.5 days at the Zimnicea station, and 67.7 days at the Reni station. The missing points in the downstream stations in column a) indicate that there was no high flow category event in a particular year as shown by the zero values in column b).

The duration of the high flow events (Fig. 6a) is increasing downstream of the Danube due to increasing mean discharges at the stations. Simultaneously, the number of events (Fig. 6b) in the category of high flows is decreasing with increasing discharges along the Danube River. The mean annual number of events in the high flow category is 7.3 at the Hofkirchen station, 6.7 at the Bratislava station, 1.54 at the Zimnicea station, and 0.85 at the Reni station.

We can also observe a trend in the changes in the durations of high flow pulses and in the frequency of their occurrence. The duration of the events in the high flow pulse category is decreasing at the Bratislava, Zimnicea, and Reni stations. At the Hofkirchen station a decrease is visible after 1985. Fig. $6 \mathrm{~b}$ shows an increasing trend in the number of events in the high flow pulse category during the year. 

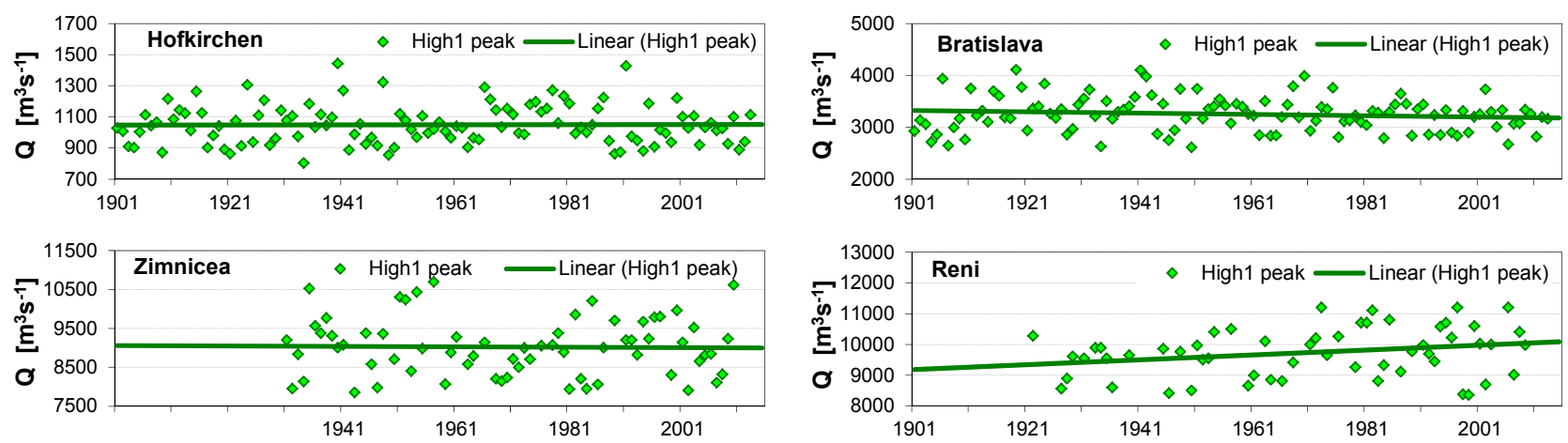

Fig. 5. Course of the mean maximum discharge of the high flow pulse category (green points) for the Hofkirchen (1901-2014), Bratislava (1901-2014), Zimnicea (1931-2010), and Reni (1921-2010) gauge stations. Green lines: long-term trends.
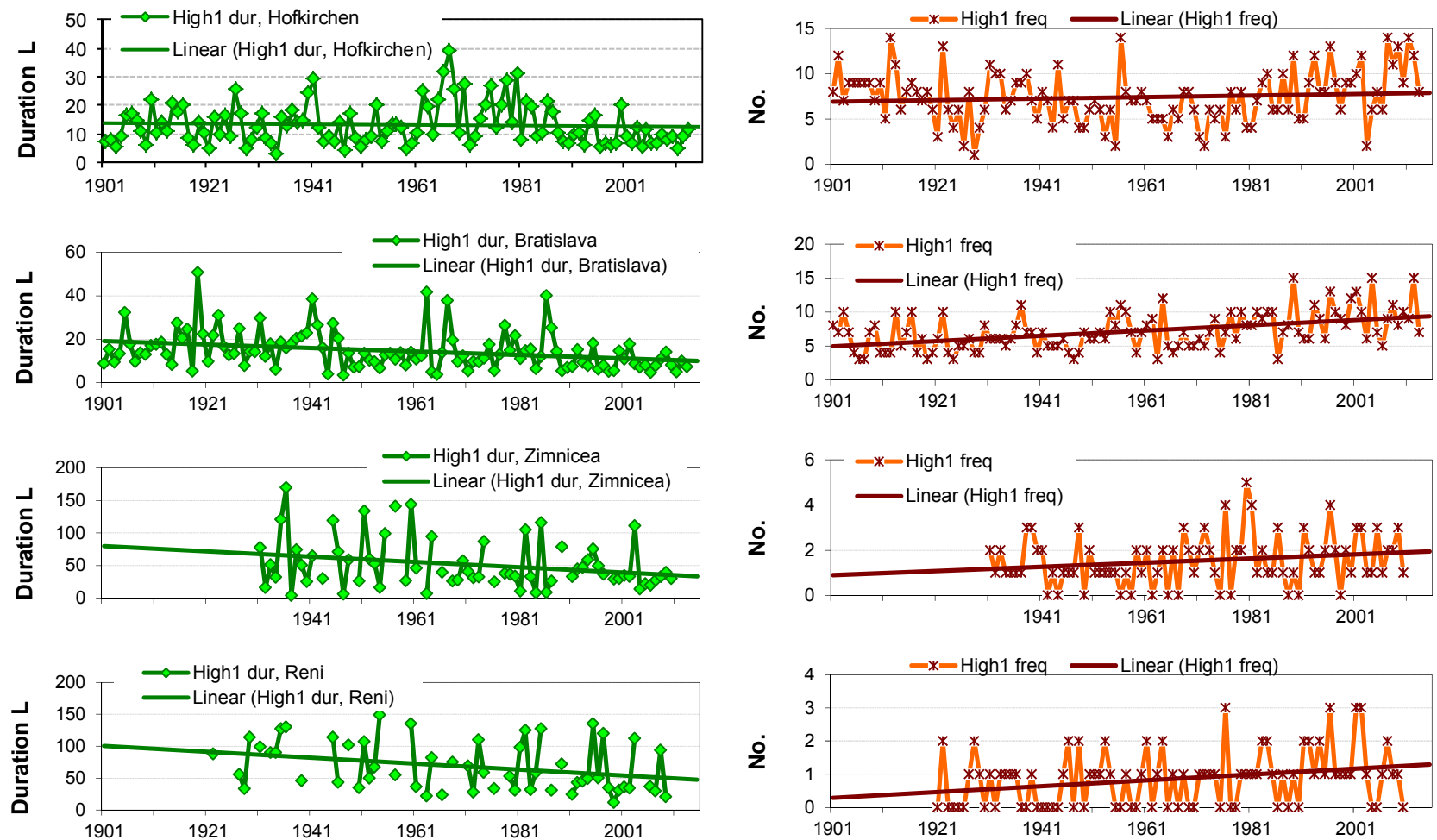

a)

Fig. 6. Course of the selected high flow pulse characteristics in four selected gauges (Hofkirchen, Bratislava, Zimnicea and Reni): a) green points: mean high flow pulses duration; green line: linear trend; b) orange points: high flow pulses frequency during year; orange line: linear trend.

The increase in the mean rate of the changes in discharges per day during the rising and falling limbs of a flood wave is related to the increasing number of events in the high flow pulse category and the decreasing duration of such events.

Fig. 7 shows the long-term trends in the changes in mean discharges per day of the high flow events during the rising limb (upper) and falling limb (bottom) of the waves at the Hofkirchen and Bratislava stations.

The results of the analysis of the trend of the five selected characteristics are summarized in Table 3 for the high flow pulse category at all the 20 stations and for the whole period of the observations.

Table 3 shows that the duration of the events in the high flow pulse category is decreasing in 19 of the stations on the Danube. The decrease is significant at a significance level of 0.01 at the Linz, Vienna, Bratislava, and Orsova stations. The frequency of the high flows is increasing at all 20 stations.
Also, the rising and falling rate of the high flow pulse category is increasing in a majority of the stations (rising rate at 14 stations and falling rate at 17 stations). This means that there are more high flow events, but their duration is shorter. This is valid for the upper, central, and lower Danube areas.

In a similar fashion we analysed the long-term trends of the five selected characteristics of the high flow events classified into the categories called "small floods" and "large floods". The results of the analysis for all the relevant gauging stations along the Danube River are summarized in Table 4 . In Fig 8 a, b only trends for the Bratislava station are presented as a typical example. The Bratislava discharge series are of a high quality, and the water levels have been available since 1823 . We processed the mean daily discharges for the period 1876-1900 using the historic rating curve based on the first Danube discharge measurements in 1882-1903, which are available at the Bratislava profile (Pekárová et al., 2014). 
Table 3. Slope coefficients of the linear trends of the high flow pulses characteristics analyzed (frequency, mean peak, duration, rising and falling rate) for the twenty gauging stations downstream of the Danube River; the + (red color)/- (black color) signs in the bottom row indicate the tendency prevailing in the majority of the stations; the trends in significance for the significance level of 0.01 are emphasized in bold type.

\begin{tabular}{llccccc}
\hline & & & & High flow pulses & \\
frequency & rise rate & fall rate* \\
\hline 1 & Berg 1930-2013 & -0.054 & -0.042 & 0.031 & 0.008 & -0.006 \\
2 & Ingolstadt 1924-2013 & -0.218 & 0.005 & 0.026 & -0.139 & 0.022 \\
3 & Regensburg 1924-2013 & -0.745 & -0.026 & $\mathbf{0 . 0 6 2}$ & 0.101 & -0.068 \\
4 & Pfeling 1926-2014 & -0.192 & -0.038 & $\mathbf{0 . 0 3 9}$ & $\mathbf{0 . 3 6 5}$ & $-\mathbf{0 . 1 4 7}$ \\
5 & Hofkirchen 1901-2014 & -0.046 & -0.013 & 0.008 & 0.275 & -0.075 \\
6 & Achleiten 1901-2014 & 0.037 & -0.021 & 0.016 & -0.102 & -0.058 \\
7 & Linz 1931-2007 & -2.022 & $-\mathbf{0 . 1 2 3}$ & $\mathbf{0 . 0 4 0}$ & -0.306 & -0.440 \\
8 & Stein-Krems 1900-2006 & -0.607 & -0.040 & $\mathbf{0 . 0 3 7}$ & 0.548 & $-\mathbf{0 . 3 6 2}$ \\
9 & Wien 1900-2006 & -1.156 & $\mathbf{- 0 . 0 5 3}$ & $\mathbf{0 . 0 3 4}$ & 0.835 & $-\mathbf{0 . 5 4 2}$ \\
10 & Bratislava 1876-2013 & -0.626 & $-\mathbf{0 . 0 9 9}$ & $\mathbf{0 . 0 3 5}$ & $\mathbf{1 . 2 8 3}$ & $-\mathbf{0 . 6 4 2}$ \\
11 & Nagymaros 1893-2007 & -0.294 & -0.030 & 0.002 & -0.268 & 0.314 \\
12 & Mohacs 1930-2007 & 0.678 & -0.184 & 0.008 & 1.446 & $-\mathbf{1 . 2 9 9}$ \\
13 & Bezdan 1931-2010 & 0.981 & -0.124 & $\mathbf{0 . 0 1 9}$ & 0.622 & -0.630 \\
14 & Bogojevo 1931-2009 & 1.357 & -0.136 & 0.012 & 0.470 & -0.730 \\
15 & Pancevo 1931-2007 & -4.300 & -0.195 & $\mathbf{0 . 0 1 9}$ & 0.029 & $-\mathbf{1 . 3 2 8}$ \\
16 & Veliko Gradiste 1931-2007 & -4.848 & -0.485 & 0.030 & 1.315 & -1.273 \\
17 & Orsova 1850-2005 & -1.758 & $-\mathbf{0 . 3 2 1}$ & $\mathbf{0 . 0 2 8}$ & 1.266 & -1.073 \\
18 & Zimnicea 1931-2010 & -0.547 & -0.408 & 0.009 & -1.490 & -0.390 \\
19 & Reni 1921-2010 & 7.905 & -0.467 & 0.009 & 1.216 & -1.849 \\
20 & Caetal Izmail 1931-2010 & 2.565 & -0.513 & 0.002 & -2.570 & 0.086 \\
\hline
\end{tabular}

*in case of fall rate the negative signs indicate increase
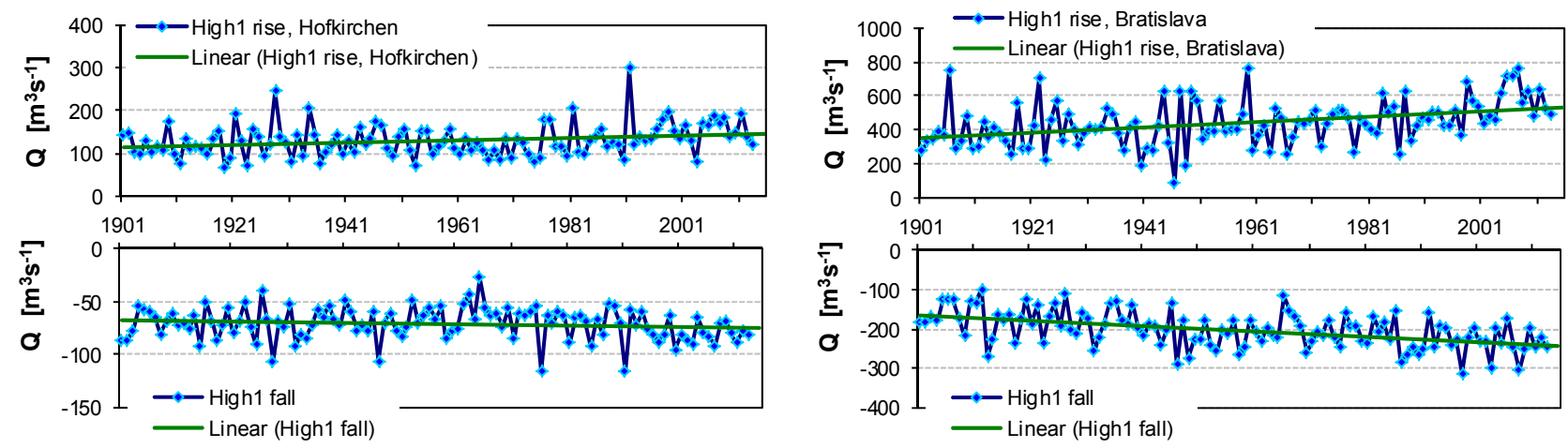

Fig. 7. Rate of changes in discharges per day at Hofkirchen (left side figures) and Bratislava (right side figures); upper figures: the rising rate, and bottom figures: falling rate in $\mathrm{m}^{3} \mathrm{~s}^{-1}$ per day.

As was mentioned above, events at the Bratislava station with maximum mean daily discharges between $5,320 \mathrm{~m}^{3} \mathrm{~s}^{-1}$ and $8,239 \mathrm{~m}^{3} \mathrm{~s}^{-1}$ were classified in the category of small floods, and events with maximum mean daily discharges higher than $8,239 \mathrm{~m}^{3} \mathrm{~s}^{-1}$ were classified in the category of large floods. The mean durations of the small and large floods are 37.8 days and 52 days per year, respectively, at the Bratislava station. The missing points in Fig. 8 indicate that there was no small or large flood category event in a particular year.

The long-term trends in the selected characteristics of the small floods are very similar to the trends of the high flow pulses (Figs. 6 and 7 compared to Fig. 8a). The magnitude of the small flood events is not changing significantly in Bratislava; the duration of small floods is decreasing; and their mean number per year is increasing. An increase in the rate of the changes in the discharges per day during the rising and falling limbs of a flood wave was observed in the small flood category as well.
The developments are different for the category of large floods. The first four characteristics do not show any significant changes in Bratislava; only a decrease in the rate of the changes in discharges per day during the falling limb of the flood waves is expressed. The results of the trend analysis of the five selected characteristics are summarized in Table 4 for the small flood and large flood category events at all 20 stations and for the whole period of the observations (according to Table 1).

In the categories of small and large floods, the significance of the long-term trends is lower, and the trends are not the same along the Danube River. In Bratislava the trend of the falling rate is decreasing (the negative numbers indicate an increase in the case of the falling rate), and it is the only station which shows such a tendency. Therefore, we proved this fact with another independent approach.

We processed flood waves of a 21-day duration for each maximum annual discharge Qmax. Fig. 9 shows the increase in the Qmax flood wave extremality at Bratislava. This figure shows 
Table 4. Slope coefficients of the linear trends of the small and large flood characteristics analyzed (frequency, mean peak, duration, rising and falling rates) for the twenty gauging stations downstream of the Danube River; the + (red color)/- (black color) signs in the last column indicate the tendency prevailing in the majority of the stations; the trend in significance on a significance level of 0.01 is emphasized in bold type.

\begin{tabular}{|c|c|c|c|c|c|c|c|c|c|c|}
\hline & peak & duration & $\begin{array}{c}\text { Small } \\
\text { Flood } \\
\text { frequency }\end{array}$ & rise rate & fall rate & peak & duration & $\begin{array}{c}\text { Large } \\
\text { Flood } \\
\text { frequency }\end{array}$ & rise rate & fall rate \\
\hline Berg & -0.122 & 0.216 & 0.002 & 0.000 & 0.029 & -0.041 & 0.051 & 0.000 & -0.541 & -0.068 \\
\hline Ingolstadt & -0.178 & -0.014 & 0.000 & 0.297 & -0.139 & 1.318 & -0.018 & 0.000 & 0.109 & -0.843 \\
\hline Regensburg & -1.112 & -0.016 & -0.001 & 1.540 & 0.311 & 1.218 & 0.171 & 0.003 & -0.973 & -0.308 \\
\hline Pfeling & -0.139 & 0.003 & 0.001 & 1.198 & 0.285 & 4.958 & -0.173 & 0.002 & -0.056 & -0.954 \\
\hline Hofkirchen & 0.958 & -0.024 & 0.002 & 0.781 & 0.255 & 2.837 & -0.121 & 0.002 & 1.277 & -0.772 \\
\hline Achleiten & -0.198 & -0.291 & 0.000 & 1.648 & -0.583 & -0.644 & -0.259 & 0.002 & 1.347 & -0.145 \\
\hline Linz & -2.201 & -0.406 & 0.002 & 5.837 & -1.879 & -23.410 & -0.882 & 0.001 & 4.247 & -2.536 \\
\hline Stein-Krems & 0.619 & -0.098 & 0.003 & 3.467 & -0.489 & 13.980 & -0.056 & 0.002 & 2.050 & -0.090 \\
\hline Wien & 1.708 & -0.139 & 0.002 & 4.699 & -0.249 & 2.787 & -0.154 & 0.002 & 5.187 & -0.348 \\
\hline Bratislava & 0.057 & -0.248 & 0.003 & 4.732 & -0.257 & 3.693 & 0.043 & 0.000 & -0.272 & 2.971 \\
\hline Nagymaros & -2.796 & -0.329 & -0.001 & 1.958 & -0.770 & 6.952 & 0.109 & 0.001 & -0.980 & -1.323 \\
\hline Mohacs & -2.755 & -0.915 & 0.005 & 1.782 & -0.971 & -1.163 & -0.757 & 0.002 & -2.471 & 1.332 \\
\hline Bezdan & 3.921 & -1.431 & -0.003 & 2.189 & -1.197 & 8.742 & -2.230 & 0.002 & 2.847 & -1.030 \\
\hline Bogojevo & 4.346 & -1.284 & -0.001 & 2.224 & -1.330 & 20.990 & -0.268 & -0.002 & -0.765 & -0.545 \\
\hline Pancevo & 5.487 & -0.074 & -0.004 & 0.032 & 0.131 & 22.400 & 0.566 & -0.001 & -1.498 & -0.085 \\
\hline Veliko Gradiste & -6.673 & -0.600 & -0.003 & 1.883 & -0.913 & 11.000 & -0.511 & 0.001 & 1.885 & -0.498 \\
\hline Orsova & 1.861 & -0.589 & 0.002 & 1.155 & -0.692 & 1.030 & -0.438 & 0.000 & 0.686 & -0.762 \\
\hline Zimnicea & -8.442 & -0.782 & 0.004 & 0.241 & -0.231 & 19.580 & -0.083 & -0.002 & -0.130 & -0.660 \\
\hline Reni & -0.970 & -1.135 & 0.003 & 1.336 & -0.750 & 4.397 & -1.536 & 0.002 & 1.910 & -0.207 \\
\hline \multirow[t]{2}{*}{ Caetal Izmail } & -13.620 & -1.155 & 0.004 & 0.102 & 0.135 & 11.100 & 0.610 & 0.002 & -1.838 & -0.650 \\
\hline & & - & + & + & + & + & - & & & + \\
\hline
\end{tabular}
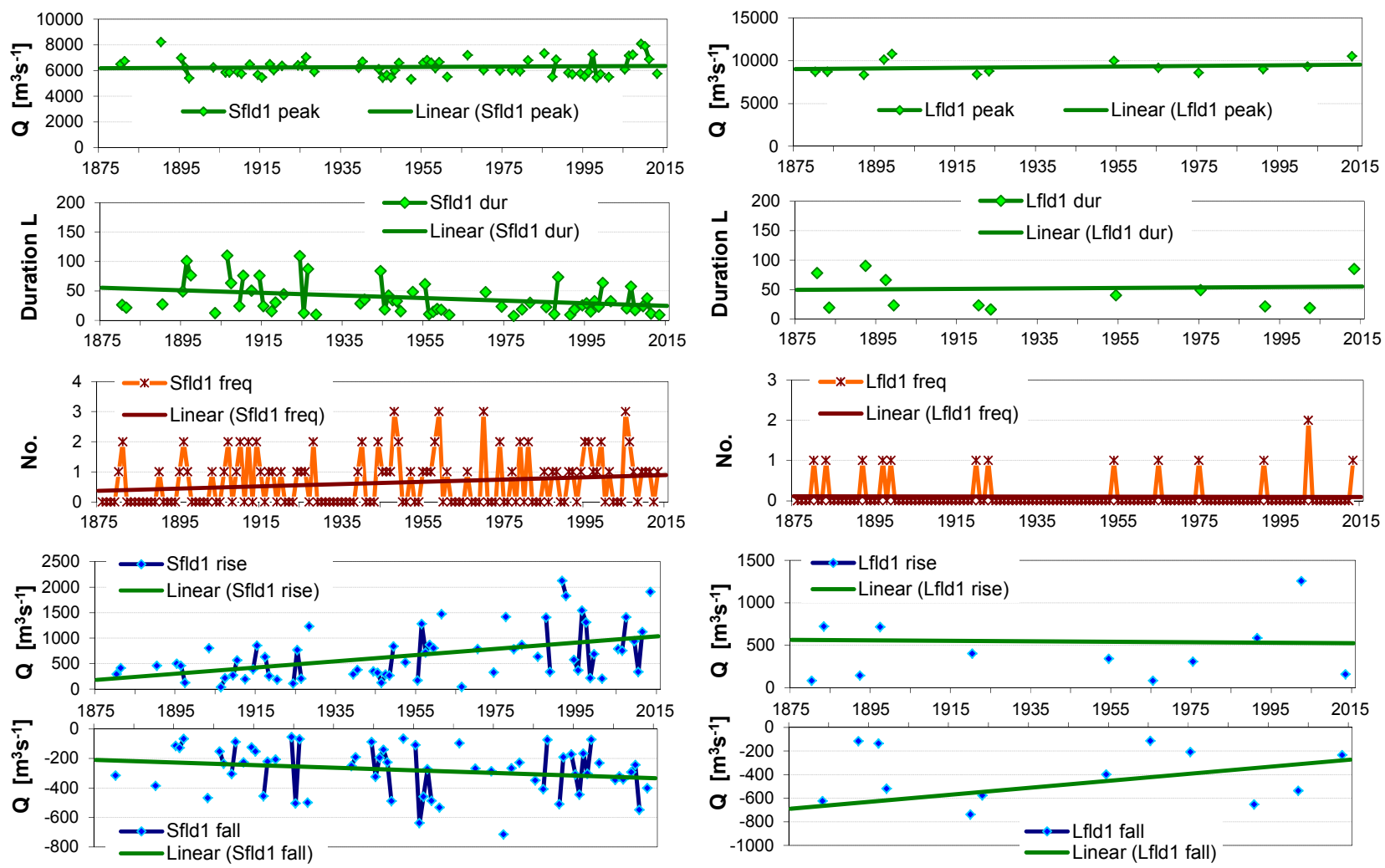

a)

b)

Fig. 8. Time course (points) and linear trends (green line) in the selected discharge characteristics (peak discharges, number and duration of events, and rising and falling rates of the waves) for small and large flood categories: left side (a) Sfld1 - small floods; right side (b) Lfd1 - large floods; at the Bratislava water gauge, 1876-2013 period. 

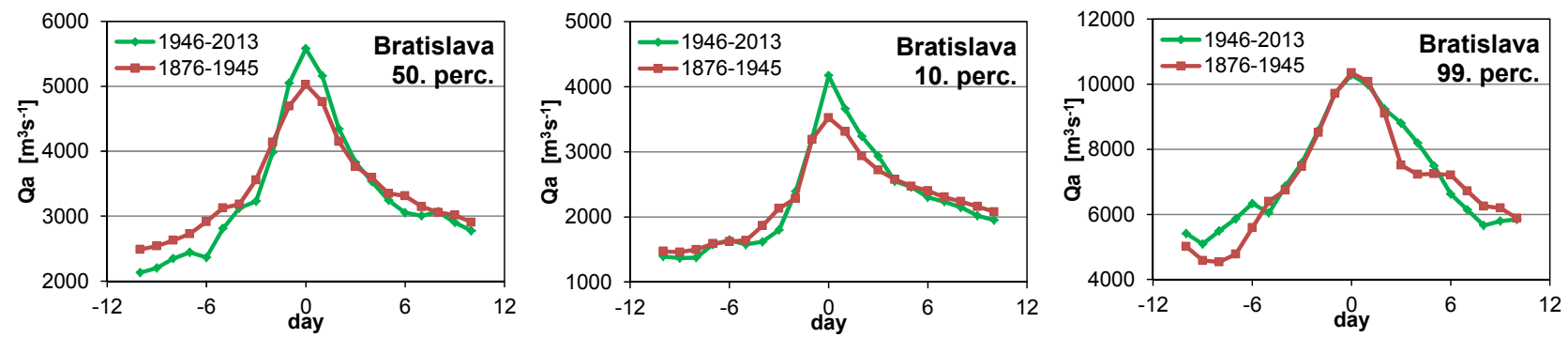

Fig. 9. Hydrographs of the median, $10^{\text {th }}$ and $99^{\text {th }}$ percentiles of the Qmax flood waves of 21 days' duration, periods: 1876-1945 and 19462013, Bratislava station.

the hydrographs of the median $\left(50^{\text {th }}\right.$ percentile $)$ of the 138 Qmax waves with durations of 21 days in two different periods (1876-1945 and 1946-2013). It is obvious that the wave magnitudes (as well as the rising and falling rates) are higher in the recent period in the case of the $10^{\text {th }}$ and $50^{\text {th }}$ percentiles, but the volume of the waves is the same in both periods. In the case of the $99^{\text {th }}$ percentiles (large floods), there are no changes.

While the high-flow events and small floods demonstrate a significant increase in the frequency of occurrences and the rising rate of the waves, in the case of large floods we have to be more cautious in our judgments. The number of floods with a return period above 10 years is too small, and one exceptional flood can markedly influence the trend. The upper Fig. 8b shows a very small change in the magnitude of the large floods (13 floods included). Therefore, it is more suitable to use the maximum annual discharge series Qmax for the analysis of the flood trends (138 years in the case of Bratislava). The maximum annual discharge Qmax at the Danube stations with the longest series of observations (Hofkirchen, Kienstock/Stein Krems, Bratislava and Orsova/Turnu Severin) and their longterm trends are shown in Fig. 10. The increase in the magnitude of the floods is more significant.

\section{DISCUSSION AND CONCLUSIONS}

The Danube River basin, i.e., the main stream as well as its tributaries, is often examined with respect to extreme flooding (Bačová Mitková et al., 2015; Blöschl et al., 2013, 2015; Brilly, 2010; Parajka et al., 2009, 2010; Pekárová et al., 2008). An investigation of the history of the frequency, severity, importance, and duration of the flood events for a region provides a greater understanding of the region's flood event characteristics and the probability of the recurrence of events. This type of information is beneficial in the development of protection and mitigation strategies and preparedness plans. Monitoring the flow of the Danube River has a long tradition, which gives us the opportunity to compare different extremes (floods as well as low flows) at different times. For example, Blöschl et al. (2013) analyzed the June 2013 flood in the Upper Danube Basin and subsequently compared it with the 2002, 1954 and 1899 floods. Changes in the water levels between the Kienstock and Bratislava water gauging stations at different time periods were analyzed by Bačová Mitková et al. (2015). Sixty-eight (68) maximum water levels over $300 \mathrm{~cm}$ (simultaneously at Kienstock and at Bratislava) were found. Empirical relationships between the water stages at Kienstock and Bratislava and between the water stage at Kienstock and flood travel time from Kienstock to Bratislava were found using data from the period 1999-2013. The results show that the travel time from Kienstock to Bratislava decreased significantly in the case of small and medium flood peaks, but the travel time of the peaks of the last extreme Danube floods (with return pe-
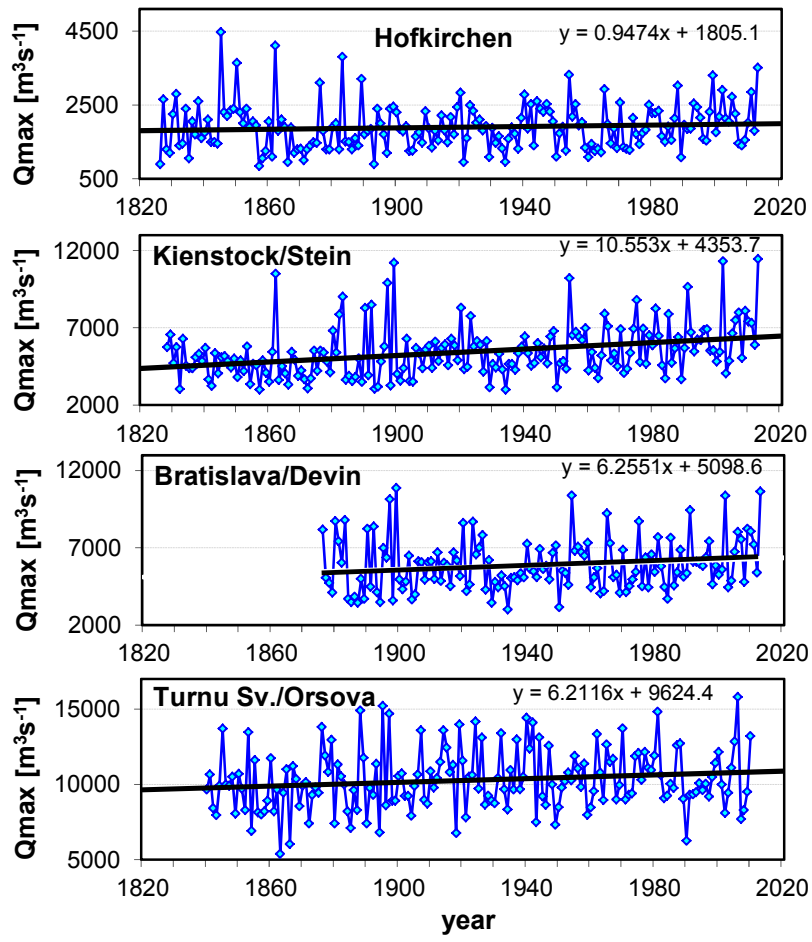

Fig. 10. The long-term trends of the maximum annual discharges Qmax in the Danube stations with the longest series of observations. (in equations: $\mathrm{y}-\operatorname{Qmax}, \mathrm{x}-\mathrm{year}$ minus 1820).

riods above 50 years) did not change. Zsuffa (1999) statistically analysed the daily water level data from four gauging stations along the Hungarian Danube reach with the purpose of analysing the impact of the Austrian hydropower plants on the floods of the river. The conditional probability distribution functions of the annual flood load maxima and the annual number of floods were generated for the periods 19571976 and 1977-1996. From the comparison, it could be seen that the flood load maxima has decreased, while the number of small and medium floods has increased during the 1977-1996 period.

Our study aimed at analysing flood regime changes along the Danube River (at 20 Danube gauging stations) during the whole observation period at each station. The findings of the study provide an insight into the changing runoff behaviour during long periods of observations. The analysis of the longterm trends of the five hydrological characteristics (peak discharges, number and duration of events, and rising and falling rates of the waves) for the three categories (high flow pulses, small floods, and large floods) in all the 20 stations along the Danube gave the same results, but from another point of view. Our study suggests that the selected flow characteristics of the Danube have changed (e.g., the duration 
of high flow pulses and small as well as large floods have decreased at almost all the stations; the rising and falling rates of the high flow pulses and small flood events have increased at all the stations). These results show that while the characteristics of the high flow pulses and small floods on the Danube have changed significantly, in the case of floods with a return period over 10 years, the changes in the statistical characteristics are not statistically significant.

The reasons for the higher rising and falling rates of the flood waves are probably partially due to the training of the Danube channel, i.e., the construction of dams and a decrease in the inundation areas. High flow pulses (with a return period of less than 2 years) and small (with a return period between 2-10 years) flood waves are moving downstream with a much higher degree of celerity with decreasing travel times. In the case of extreme floods (with a return period above 10 years), the travel time is not significantly changing, as was mentioned above.

The operation of waterworks on the tributaries and the Danube itself as well as the increase in air temperatures has modified the mean monthly discharge regime of the Danube, i.e., increasing winter-spring discharges and decreasing summer discharges. The contribution of individual factors is not possible to determine by an analysis of only the discharge series. Changes in the precipitation regime may also be the cause of the increase, so it is also necessary to analyze the changes in the meteorological components, i.e., precipitation, air temperature and evapotranspiration. Blöschl et al. (2015) reviewed whether floods have changed in the past. In Europe, the magnitude and frequency of floods have indeed changed in a complex manner with alternating flood-rich and flood-poor periods. In some parts of Europe, the present time may be a flood-rich period. While increasing river flood runoff is a reality rather than a fiction at some locations, depending on their influencing factors (precipitation, temperature changes), in many regions the socioeconomic conditions have changed even more, resulting in increases in flood damage. According to the Blöschl et al. (2015) study, an integrated flood risk management approach is needed for dealing with future flood risks with a focus on reducing the vulnerability of the societal system.

It would be useful in further research to focus on an analysis of the flood regime changes in the individual seasons of the year. We could subsequently evaluate and describe flow events that occur at different times of the year in the same river basin that have a distinct origin (e.g., floods resulting from rain, rain on snow, and floods due to snowmelt).

Acknowledgement. This work was supported by the VEGA project under Contract No. 2/0009/15 "Identification of changes in hydrological regime of streams and mutual relation of extreme hydrologic events in complex river system of the Danube basin" and results from the project's implementation of the "Centre of excellence for integrated flood protection of land" (ITMS 26240120004) supported by the Research \& Development Operational Programme funded by the ERDF. In this study, daily discharges from the database of the project "Flood regime of rivers in the Danube River basin" and "Global Runoff Data Centre" in Koblenz were used.

\section{REFERENCES}

Bačová Mitková, V., Halmová, D., Pekárová, P., Miklánek, P., 2015. Analysis of the Danube water stage changes at Bratislava. In: Proceedings of the International Multidisciplinary Scientific GeoConference SGEM 2015, vol. 1. Hydrology and Water Resources, pp. 41-48. ISBN 978-619-7105-36-0. ISSN 1314-2704.

Beurton, S., Thieken, A.H., 2009. Seasonality of floods in Germany. Hydrological Sciences Journal, 54, 1, 62-76.

Blöschl, G., Merz, R., Parajka, J., Salinas, J., Viglione, A., 2012. Floods in Austria. In: Kundzewicz, Z.W. (Ed.): Changes in Flood Risk in Europe, Chapter 8. IAHS Press, Wallingford, UK, pp. 169-177.

Blöschl, G., Nester, T., Komma, J., Parajka, J., Perdigao, R.A.P., 2013. The June 2013 flood in the Upper Danube Basin, and comparisons with the 2002, 1954 and 1899 floods. Hydrology and Earth System Sciences, 17, 12, 5197-5212.

Blöschl, G., Gaál, L., Hall, J., Kiss, A., Komma, J., Nester, T., Parajka, J., Perdigao, R.A.P., Plavcová, L., Rogger, M., Solinas, J.L., Viglione, A., 2015. WIREs Water 2015, 2, 329344. doi: $10.1002 /$ wat 2.1079.

Brilly, M., 2010. Hydrological Processes of the Danube River Basin. Springer, Dordrecht, 328 p. doi 10.1007/978-90-4813423-6.

Gao, Y., Vogel, R.M., Kroll, Ch.N., Poff, N.L., Olden, J.D., 2009. Development of representative indicators of hydrologic alteration. Journal of Hydrology, 374, 136-147. doi: 10.1016/j.hydrol.2009.06.009.

Hall, J., Arheimer, B., Borga, M., Brázdil, R., Claps, P., Kiss, A., Kjeldsen, T.R., Kriaučiūniené, J., Kundzewicz, Z.W., Lang, M., Llasat, M.C., Macdonald, N., McIntyre, N., Mediero, L., Merz, B., Merz, R., Molnar, P., Montanari, A., Neuhold, C., Parajka, J., Perdigao, R.A.P., Plavcová, L., Rogger, M., Salinas, J.L., Sauquet, E., Schär, C., Szolgay, J., Viglione, A., Blöschl, G., 2014. Understanding flood regime changes in Europe: a state-of-the-art assessment. Hydrology and Earth System Sciences, 18, 7, 2735-2772. ISSN 10275606, http://dx.doi.org/10.5194/hess-18-2735-2014.

Hersh, E.S., Maidment, D.R., 2006. Assessment of Hydrologic Alteration Software. Final report, submitted in Fulfillment of TWDB Project \#2005-483-029. Center for Research in Water Resources, The University of Texas at Austin, Austin, $114 \mathrm{p}$.

Holčík, J., 2003. Changes in the fish fauna and fisheries in the Slovak section of the Danube River: a review. Ann. Limnol. - Int. J. Lim. 39, 3, 177-195.

Junk W.J., Bayley, P.B., Sparks, R.E., 1989. The flood pulse concept in river floodplain systems. Can. Spec. Publ. Fish. Aquat. Sci., 106, 110-127.

Kundzewicz, Z.W., Dobrowolski, A., Lorenc, H., Niedzwiedz, T., Pinskwar, I., Kowalczak, P., 2012. Floods in Poland. In: Kundzewicz, Z.W. (Ed.): Changes in Flood Risk in Europe, Chapter 17. IAHS Press, Wallingford, UK, pp. 319-334.

Lindström, G., Bergström, S., 2004. Runoff trends in Sweden 1807-2002. Hydrol. Sci. J. 49, 69-83. http://dx.doi.org/10.1623/hysj.49.1.69.54000.

Mathews, R., Richter, B.D., 2007. Application of the indicators of hydrologic alteration software in environmental flow setting. Journal of the American Water Resources Association, 43, 1400-1413.

Merz, B., Aerts, J., Arnbjerg-Nielsen, K., Baldi, M., Becker, A., Bichet, A., Blöschl, G., Bouwer, L.M., Brauer, A., Cioffi, F., Delgado, J.M., Gocht, M., Guzzetti, F., Harrigan, S., Hirschboeck, K., Kilsby, C., Kron, W., Kwon, H.-H., Lall, U., Merz, R., Nissen, K., Salvatti, P., Swierczynski, T., Ulbrich, U., Viglione, A., Ward, P.J., Weiler, M., Wilhelm, B., Nied, M., 2014. Floods and climate: emerging perspectives for flood risk assessment and management. Nat. Hazards Earth Syst. Sci., 14, 1921-1942. doi: 10.5194/nhess-141921-2014. 
Parajka, J., Kohnova, S., Merz, R., Szolgay, J., Hlavcova, K., Bloschl, G., 2009. Comparative analysis of the seasonality of hydrological characteristics in Slovakia and Austria. Hydrological Sciences Journal, 54, 3, 456-473.

Parajka, J., Kohnova, S., Balint, G., Barbuc, M., Borga, M., Claps, P., Chaval, S., Gaume, E., Hlavcova, K., Merz, R., Pfaundler, M., Stancalie, G., Szolgay, J., Bloschl, G., 2010. Seasonal characteristics of flood regimes across the AlpineCarpathian range, Journal of Hydrology, 394, 1-2, 78-89. doi: 10.1016/ j.jhydrol.2010.05.015.

Pekárová, P., 2009. Multiannual runoff variability in the Upper Danube region. DrSc. Thesis, IH SAS, Bratislava, 151 p. http://pavla.pekarova.sk.

Pekárová, P., Onderka, M., Pekár, J., Miklánek, P., Halmová, D., Skoda, P., Bačová Mitková, V., 2008. Hydrologic scenarios for the Danube River at Bratislava. Key Publishing, Ostrava, 160 p., http://www.ih.savba.sk/danubeflood.

Pekárová, P., Miklánek, P., Balogh, E., 2011. Flood regime analysis of the Danube in 1876-2005. In: Proceedings of the 19th International Poster Day Transport of Water, Chemicals and Energy in the Soil-Plant-Atmosphere System. IH SAS, Bratislava, pp. 628-635. ISBN - 978-80-89139-26-2.

Pekárová, P., Miklánek, P., Melo, M., Halmová, D., Pekár, J., Bačová Mitková, V., 2014. Flood Marks along the Danube River between Passau and Bratislava. VEDA and the Slovak Committee for Hydrology - National Committee for the International Hydrological Programme of UNESCO (SVH - NC IHP UNESCO), Bratislava, 104 p. ISBN 978-80224-1408-1.
Petrovič, P., Nachtnebel, H., Kostka, Z., Holko, L., Miklánek, P., 2006. Basin-wide water balance in the Danube river basin. The Danube and its basin. Hydrological monograph Part VIII-3. IHP UNESCO \& VÚVH, Bratislava, 161 p. + 4 maps. ISBN 80-89062-49-0

Petrow, T., Merz, B., 2009. Trends in flood magnitude, frequency and seasonality in Germany in the period 19512002. Journal of Hydrology, 371, 1-4, 192-141.

Pyron, M., Neumann, K., 2008. Hydrologic alterations in the Wabash River watershed, USA. River. Res. Applic., 24, 1175-1184.

The Nature Conservancy, 2009. Indicators of Hydrologic Alteration, Version 7.1. User's Manual. The Nature Conservancy (publisher), $81 \mathrm{p}$.

Vorogushyn, S., Merz, B., 2013. Flood trends along the Rhine: the role of river training. Hydrol. Earth Syst. Sci., 17, 38713884. doi: 10.5194/hess-17-3871-2013.

Wachter, K., Kalas, M., Szabo, J.A., Niemeyer, S., Bodis, K., de Roo, A., 2005. Setup and testing of European Early Flood Alert System (EFAS) in the Danube River Basin. Geophysical Research Abstracts, 7, 09297. SRef-ID: 16077962/gra/EGU05-A-09297.

Zsuffa, I., 1999. Impact of Austrian hydropower plants on the flood control safety of the Hungarian Danube reach. Hydrological Sciences Journal, 44, 3, 363-371.

Received 22 March 2016

Accepted 30 September 2016 